\title{
Bogdan Góralczyk, Wielki renesans. Chińska transformacja i jej konsekwencje, Wydawnictwo Akademickie ,Dialog”, Warszawa 2018, ss. 582
}

Problematyka politycznego znaczenia Chin na świecie i przemian gospodarczych $\mathrm{w}$ tym kraju stale obecna jest w zagranicznych publikacjach jako niezbędny element debaty na temat rywalizacji chińsko-amerykańskiej czy dążenia Chińskiej Republiki Ludowej do zreformowania systemu międzynarodowego. W Polsce przez dłuższy czas traktowana była dość lekceważąco, ale od kilku lat przyciąga coraz większą uwagę, głównie ze względu na popularność teorii geopolitycznych i silniejsze stosunki pomiędzy Chinami a Polską. Aktywny udział w tej debacie bierze Bogdan Góralczyk dyrektor Centrum Europejskiego Uniwersytetu Warszawskiego i były pracownik Ministerstwa Spraw Zagranicznych (m.in. ambasador w Tajlandii), uczestnik wielu projektów naukowych i autor licznych publikacji na temat ChRL. Wielki renesans to podsumowanie wielu lat badań Autora, składające się z dwóch części: Transformacja jest szczegółowym omówieniem wydarzeń z ostatnich czterdziestu lat (sięgającym często dalej w przeszłość), a Konsekwencje - wyjaśnieniem, jak wpłynęły one na rzeczywistość współczesnych Chin. Publikację wieńczą glosariusz z chińskimi terminami, a także bibliografia i indeks nazwisk.

Autor stawia sobie dwa ambitne cele: opisać najważniejsze fakty dotyczące polityczno-gospodarczej transformacji Chin oraz towarzyszącą im ideową debatę (zarówno wewnątrz Chin, jak i za granicą) w ciągu ostatnich czterdziestu lat. Przyjęty w pracy zakres czasowy, tematyczny i problemowy jest olbrzymi i choć Autor podkreśla różnorodność współczesnych Chin, a więc konieczność uwzględniania wielu perspektyw, to widoczny jest problem z krytyczną analizą nagromadzonego materiału. Pisze mianowicie: „Nie o krytykę i polemikę mi [...] chodzi, lecz [...] pokazanie [...] innego sposobu myślenia" (s. 333), a w podsumowaniu dodaje: ,[...] był to zabieg [...] świadomy, choć bez prób wartościowania. To do Czytelnika należy, co uzna 
za lepsze czy gorsze rozwiązania" (s. 512). Takie podejście do źródeł i faktów może być uznane za zaletę, ale rodzi pytanie o wnioski. Co bowiem wynika z wielu przytoczonych przez Autora cytatów i poglądów? Przeczy to także zawartej w książce tezie na temat Chin: „Ich ranga i znaczenie są już jednak takie, by przestać wreszcie posługiwać się względem nich naszymi wizjami, uproszczeniami, [...] a nie twardą wiedzą" (s. 521). Góralczyk daje w swojej publikacji dostęp do wiedzy, ale wiedza pozbawiona eksperckiego wskazania nie jest dostatecznie twarda. Konfuzję czytelnika pogłębia specyficzny język Autora, który nierzadko w zastępstwie analizy opisywanego zjawiska czy postaci posługuje się anegdotą czy określeniami o dość pejoratywnym nacechowaniu. Czytamy więc na przykład, że „Deng [...] znowu wpadł w sidła lewaków spod znaku »bandy czworga«" (s. 35).

Opis postaci i dokonań Deng Xiaopinga jest zresztą dobrym przykładem głównego problemu Wielkiego renesansu. Autor szuka usprawiedliwień dla prowadzonej przez chińskiego przywódcę polityki, ale nie zastanawia go na przykład jego merkantylna motywacja związana z ochroną interesów Komunistycznej Partii Chin, a nie działaniem na rzecz chińskiego społeczeństwa. Wartościowa byłaby próba dyskusji z ugruntowanym wizerunkiem Denga, lecz Autor pisze zamiast tego, że bez niego „Chiny nie byłyby dzisiaj tu, gdzie są. Ta akurat konstatacja pozostaje poza wszelką dyskusją” (s. 70).

Zbyt często przywoływana jest w książce oficjalna narracja ChRL, która ze względów politycznych kieruje się dogmatami i wyklucza alternatywne rozwiązania. Góralczyk nie analizuje więc na przykład założenia o kluczowej roli KPCh we współczesnej historii Chin. Nie polemizuje z tezami o związkach przyczynowo-skutkowych między monopolem partii a modernizacją kraju, bogaceniem się społeczeństwa i utrzymaniem spójności terytorialnej. Czy wielki renesans dokonał się dzięki polityce KPCh, czy też niejako wbrew niej? Partia komunistyczna utożsamiana jest przez Autora z Chinami, co widać na przykład wtedy, gdy pisze, że reformy „mogą uratować KPCh, a Chinom zapewnić dalszy postęp i rozwój”. Najsilniej widoczne jest to podejście we fragmencie poświęconym polityce jednego dziecka, gdzie Góralczyk pisze: ,[...] w podejściu do tego trudnego zagadnienia wskazane byłoby [...] zachowanie trzeźwości, ucieczka od emocji i etykietowania [...]. Poprzestańmy może na prostej konstatacji, że [...] świat chiński jest jednak mocno odmienny od naszego" (s. 98). Dlaczego Autor utożsamia świat chiński z KPCh? Są to przecież zjawiska, które należy traktować odrębnie - dość wspomnieć, że duża część Chińczyków nie akceptowała narzucanych im zasad. Podobnie trudno zrozumieć następujący fragment: ,,[...] kolejny egzamin z adaptacji Partii [...] został pomyślnie 
zdany - choć akurat w przypadku wyznawców Falun Gong było to doświadczenie traumatyczne, wręcz brutalne" (s. 148). W całej książce nie brakuje takich stwierdzeń, zdających się doceniać totalitarną sprawność działania KPCh, tymczasem kwestia nadrzędności interesu partii nad interesem obywateli i państwa jest dla opisu zmian w Chinach kluczowa. Niejednolitość renesansu i trudność oceniania go w dużej mierze wynikają bowiem ze zmieniającej się polityki KPCh w związku z koniecznością ochrony interesów własnego środowiska. Właśnie to był priorytet, a reszta jest głównie pochodną.

Mimo że rzeczywistość chińską charakteryzują korupcja - o której Autor wspomina - i kultura guanxi, to porównując klasę polityczną ChRL do krótkowzrocznych polityków demokratycznych, Góralczyk określa ją jako „,przywódców i liderów myślących w kategoriach długoterminowych i racji stanu, a więc nadrzędnych interesów państwa, a nie partii, grupy czy jakiegokolwiek lobby” (s. 9). Dodaje następnie, że „sami Chińczycy, rozumiejąc [...] specyfikę i odmienność, wręcz zapewniają zachodnich obserwatorów, że [...] kierują się [...] przede wszystkim własnym bogatym doświadczeniem oraz trzeźwą praktyką i pragmatyzmem" (s. 13). Nie wiadomo, czy Autor podziela tę opinię i na ile ma świadomość, jak dalece nieprawdziwa jest to wizja, ale za to popularyzowana za granicą przez chiński aparat państwowy.

Góralczyk odwołuje się do neokonfucjanizmu i poglądu o „,ignorancji przeciętnego wyborcy, skąd płynie głębokie [...] przekonanie, że sprawy rządzenia [...] nie leżą w dyspozycji mas, lecz starannie dobranych i [...] wykształconych elit" (s. 309). Sęk jednak w tym, że elity w Chinach wcale nie są starannie dobrane ani też zbyt dobrze wykształcone (masowe są na przykład plagiaty prac doktorskich poszczególnych urzędników). Kryterium doboru zależne jest od stażu i doświadczenia w hierarchii partyjnej i ma charakter czysto polityczny. Jak więc rozumieć taki fragment: „Chińska długoterminowość i walka o stabilność versus zachodnia krótkowzroczność i swoiste rozedrganie to sedno tego zagadnienia [...]. My myślimy o sondażach lub co najwyżej następnych wyborach, oni o następnych pokoleniach. Dlatego mogli wyjść z tak śmiałą wizją, jak dwa Jedwabne Szlaki, zawierające w sobie wielkie geostrategiczne przesłanie" (s. 438)? Góralczyk powtarza tutaj ni mniej, ni więcej tylko przesłanie, do którego same Chiny próbują obecnie przekonać resztę świata. W swej istocie zakłada ono, że systemy demokratyczne są przyczyną destabilizacji tzw. świata zachodniego (przykładem brexit, popularność ruchów populistycznych i wybór Donalda Trumpa), a model chiński jest od nich korzystniejszy. Ten punkt widzenia pomija oczywiście opresyjny i hegemoniczny aspekt obecnej polityki ChRL. 
W Wielkim renesansie znajdziemy też inne kontrowersyjne stwierdzenia. Autor nie unika na przykład fascynacji projektem Pasa i Szlaku, ale nie pokusił się o realną ocenę negatywnego wpływu tego przedsięwzięcia na inne kraje (np. w kwestii zadłużenia) i politycznego wykorzystywania ich przez Chiny (np. Pakistanu, państw Azji Południowo-Wschodniej czy Bliskiego Wschodu). Wątpliwości budzi też na przykład fragment o rywalizacji technologicznej pomiędzy USA a ChRL, w którym uwzględniono statystyki patentów, ale już brakuje odniesienia do ich niewielkiej implementacji w Chinach. Autor pisze, że Huawei i ZTE ,są postrzegane jako poważny rywal o niejasnych koneksjach i zapleczu" (s. 107). Czy naprawdę jest to tylko kwestia postrzegania? Czy nie ma ostatnio (ale także w historii) przykładów ich podejrzanej działalności? Co najmniej niedopowiedzeniem jest także określenie Chińskiej Akademii Nauk Społecznych (CASS) mianem ,jednego z najważniejszych ośrodków niezależnego myślenia, choć pracującego na rzecz władz [...]" (s. 112), zwłaszcza wziąwszy pod uwagę zależności, jakim ta placówka podlega. $Z$ dużą swobodą Autor traktuje też proces centralizacji władzy przez Xi Jinpinga, a zwłaszcza walkę z korupcją. Słusznie podkreśla nadzwyczajną skalę podjętych działań, ale zbyt mało koncentruje się na motywacji Xi i jego środowiska politycznego. Niedostatecznie uwypukla, że kluczowym elementem kampanii było oczyszczenie szeregów KPCh ze środowisk niechętnych przewodniczącemu. Wątek ten pojawia się wprawdzie na dalszych stronach, ale jego związek z kampanią antykorupcyjną umyka czytelnikowi.

Wartością książki jest szerokie wykorzystanie źródeł w wielu językach. Autor pisze, że „należy szukać wiedzy w oficjalnych dokumentach z posiedzeń plenarnych oraz zjazdów KPCh, dostępnych w języku chińskim [...]” (s. 85). Czy nie należałoby jednak opatrzyć podobnych rekomendacji uwagą o możliwych problemach $\mathrm{z}$ ich wiarygodnością?

Wielki renesans to dzieło monumentalne, dobre podsumowanie historii współczesnych Chin i związanych z nimi zmian na arenie międzynarodowej. Wypełnia ono ważną lukę w polskiej literaturze, ponieważ tak przekrojowej książki - prezentującej nie tylko fakty ze współczesnej historii Chin, ale także spektrum idei - jeszcze na naszym rynku nie było. Czytelnikowi zainteresowanemu bieżącymi informacjami o Chinach pozwoli uporządkować fakty, poznać idee i poszerzyć wiedzę, natomiast osobie, która zajmuje się chińską polityką zawodowo, może dostarczyć wielu inspiracji. 